\title{
INDICADORES
}

\section{SCHOLARLY PUBLISHERS' INDICATORS: PRESTIGE, SPECIALIZATION, AND REVIEW SYSTEMS OF SCHOLARLY BOOK PUBLISHERS}

\author{
Scholarly Publishers Indicators: prestigio, \\ especialización y sistemas de revisión de \\ editoriales científicas
}

Elea Giménez-Toledo, Jorge Mañana-Rodríguez, and Carlos-Miguel Tejada-Artigas

Nota: Este artículo puede leerse traducido al español en:

http://www.elprofesionaldelainformacion.com/contenidos/2015/nov/18_esp.pdf

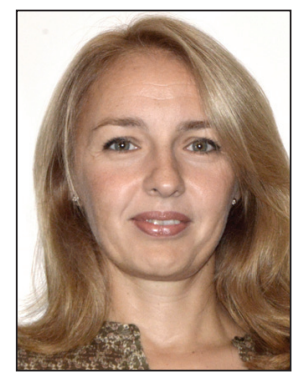

Elea Giménez-Toledo holds a PhD in information science. She is a research fellow at the Spanish National Research Council (CSIC) and she is head of the Research Group on Scholarly Books (ÍLIA), devoted to the analysis of scholarly publishing in the social sciences and humanities as well as the relationship with its environment (authors, publishers, referees, readers, and evaluation agencies). She has promoted and is co-author of Scholarly Publishers' Indicators. She is a member of the EvalHum initiative.

http://ilia.cchs.csic.es/SPI

http://www.evalhum.eu

http://orcid.org/0000-0001-5425-0003

Centro de Ciencias Humanas y Sociales, CSIC Albasanz, 26-28. 28037 Madrid, España elea.gimenez@cchs.csic.es

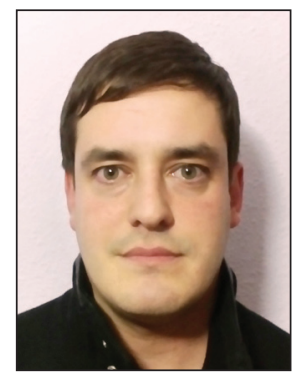

Jorge Mañana-Rodríguez holds a PhD in information science. He is a hired researcher at the Philosophy Institute at the Spanish National Research Council (CSIC), specializing in social sciences and humanities publications. He is a member of the ÍLIA research group and co-author of Scholarly Publishers' Indicators.

http://ilia.cchs.csic.es/SPI

http://orcid.org/0000-0002-0717-5271

Centro de Ciencias Humanas y Sociales, CSIC Albasanz, 26-28. 28037 Madrid, España jorge.mannana@cchs.csic.es

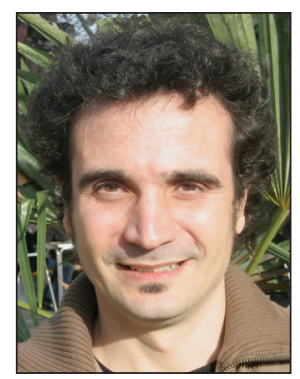

Carlos-Miguel Tejada-Artigas, PhD in information science, is a tenured lecturer at the School of Information and Library Sciences at Universidad Complutense de Madrid. He is a member of the ÍLIA research group and co-author of Scholarly Publishers' Indicators.

http://ilia.cchs.csic.es/SPI

http://orcid.org/0000-0002-2767-5636

Universidad Complutense de Madrid, Facultad de Ciencias de la Documentación Santísima Trinidad, 37. 28010 Madrid, España cmtejada@ucm.es 


\begin{abstract}
This work presents the updated version of the public information system SPI (Scholarly Publishers' Indicators), developed by ÍLIA (research group on scholarly books), which belongs to the Spanish National Research Council. SPI contains three types of indicators about book publishers: prestige according to expert opinions; thematic specialization according to Dilve (information on Spanish books for sale) classification; and manuscript selection procedures according to each publisher's answers to a survey. SPI Expanded is also described as an information system which provides information about each scholarly publisher's indexation in four international information systems. The methodological specifications for the design of SPI Expanded in each of the dimensions are presented. Finally, the functionalities and current use as a reference in the assessment process of scholarly publishers' output are detailed.
\end{abstract}

\title{
Keywords
}

Book assessment; Scholarly publishers; Scientific monographs; Thematic specialization; Publishers' prestige; Humanities; Social sciences; Scientific assessment; SPI; Scholarly Publishers' Indicators.

\section{Resumen}

Se presenta la versión más actualizada del sistema público de información SPI (Scholarly Publishers Indicators), desarrollado por el Grupo de Investigación sobre el Libro Académico (ÍLIA) del CSIC. SPI aúna ya tres tipos de indicadores para editoriales académicas: prestigio editorial a partir de la opinión de los investigadores; especialización temática según la clasificación de libros en Dilve (Distribuidor de información del libro español en venta); v procesos de selección de originales a partir de la información declarada por las propias editoriales mediante encuestas. Se describe también SPI Expanded, un análisis de la presencia de editoriales académicas en cuatro sistemas de información internacionales. Por otra parte, se facilitan las especificaciones metodológicas que han conducido al diseño de SPI Expanded en cada una de sus dimensiones, así como las funciones presentes en el mismo y su actual utilización como referencia en los procesos de evaluación.

\section{Palabras clave}

Evaluación de libros; Editoriales académicas; Monografías científicas; Especialización temática; Prestigio editorial; Humanidades; Ciencias sociales; Evaluación científica; SPI; Scholarly Publishers Indicators.

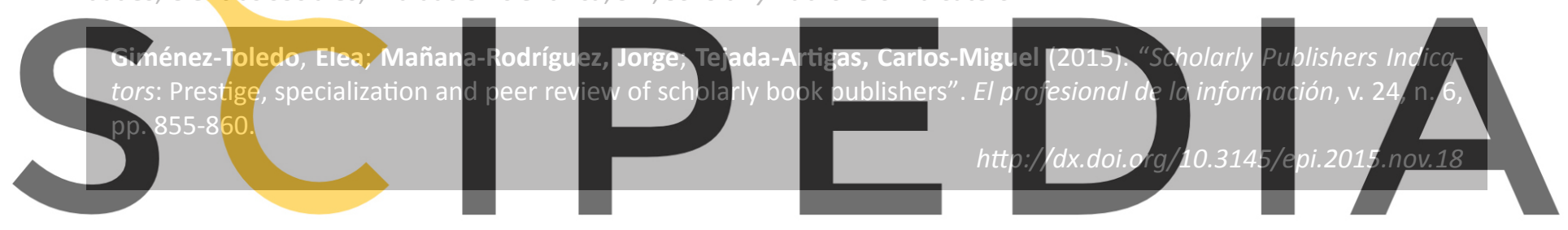

\section{Registentforluferenat https//www.scipedia.com to dowindojadithe version without the watermark}

The relevance of using books for assessing outputs in social sciences, and more specificaliy in the humanities, is rooted in solid evidence (Hicks, 2004; Engels; Ossenbklok; Spruyt, 2012). Nevertheless, the systems developed by the companies which commercialize bibliometric indicators (Thomson Reuters, Scopus) (Adams; Testa, 2011) present relevant weaknesses which limit their possible use, including the indicator on which they are based: citations. The problems associated with citation-based metrics are well known (in some cases by researchers foreign to the discipline of library and information science), despite their continuous use (Wilcox, 2008; Kumar, 2010; Adler; Ewing; Taylor, 2009). Criticism of citation-based metrics goes far beyond their inappropriate usage by evaluators; some of these criticisms do, in fact, compromise the mathematical validity as information sources (Adler, Ewing and Taylor, 2009). In recent years, research has shown there are other possible and solid approaches for the analysis of books, book publishers, and book collections. These other approaches have generated indicators and information which can be useful for scientific assessment. Some of the approaches relate to the study of scholarly book publishers and are integrated into the information system Scholarly Publishers' Indicators (SPI).
The necessity of a proper assessment of scientific output (Frølich, 2011); the lack of information about systems that are susceptible of being used with evaluative aims in the social sciences and the humanities (including its main communication channel: the book); and the need for knowing the book publishers' core relevant to Spanish scholars (as a basic research aim) are the main reasons for the development of the SPI information system.

\section{SPI Contents}

$S P I$ is comprised of three categories and each includes information and indicators: 1) Publishers' prestige rankings (both for Spanish and non-Spanish book publishers). This ranking is the result of a large scale survey sent to researchers in 16 knowledge fields in two waves. 2) Information regarding the publishers' thematic specialization, and 3) Information regarding the assessment systems (peer review, etc.) which the publishers declare they use.

\subsection{Book publishers' rankings}

A survey was designed to identify the most prestigious book publishers in different disciplines. Among some other questions, the respondents were asked to point to the 10 most 


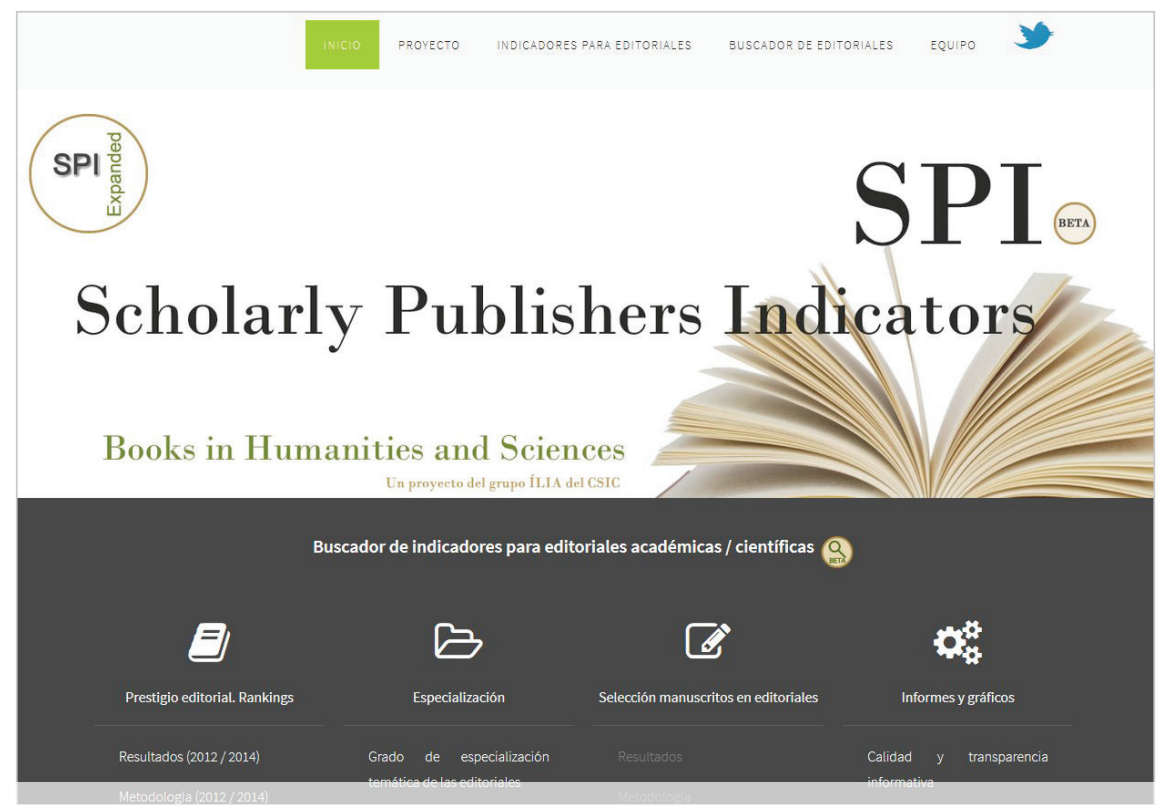

Figura 1. http://ilia.cchs.csic.es/SPI
The processing of this information resulted in the general book publishers' prestige rankings (both for Spanish and non-Spanish publishers), and the homologous calculation, taking into account the discipline each respondent is affiliated with, allowed the development of the various discipline rankings which are available at SPI.

http://ilia.cchs.csic.es/SPI/ prestigio_sectores_2014.php

The disciplines for these rankings include: fine arts, anthropology, archaeology and prehistory, library and information science, communication, economics, education, hebrew and arabic studies, law, philosophy, geography, history, linguistics, literature and philology, political science, psychology, and sociology. prestigious book publishers according to their relevance. The survey was sent to over 11,000 lecturers with a six year research period and positively evaluated by one of the two main Spanish assessment agencies (Cneai) or counting with a positive assessment by Aneca (tenure). The response rate
General rankings have been transformed into interactive charts which allow the ascending or descending visualization of the indicator for each discipline. I.e., see non-Spanish publishers:

http://ilia.cchs.csic.es/SPI/grafico4_extr.html
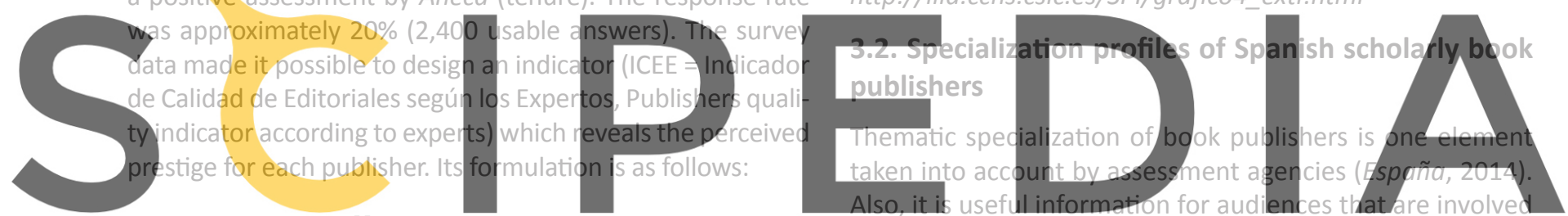

ICEE $=\sum_{i=1}^{i=10} n_{i} \frac{N_{i}}{N_{i}}$

Register for free at https//www.scipedia.com to download the version without the watermark Where:

$N_{i}=$ Is the number of votes received by the publisher in the position i (from 1 to 10)

$N_{i}=$ Is the number of votes received by all publishers in all positions

$\frac{N_{i}}{N_{j}}=W_{j}$

$W_{j}=$ Is the weight assigned to the number of votes received by each publisher.

In all cases the condition $W_{1}>W_{2}>W_{K} . .>W_{10}$ is fulfilled. This condition is needed in order to guarantee that the weights assigned to each position correspond to their sense (a higher weight attached to those publishers considered the most prestigious). This weighting system is distributiondependent; this excludes any possibility of arbitrariness in assigning the weights by the researchers (Giménez-Toledo; Tejada-Artigas; Mañana-Rodríguez, 2013).

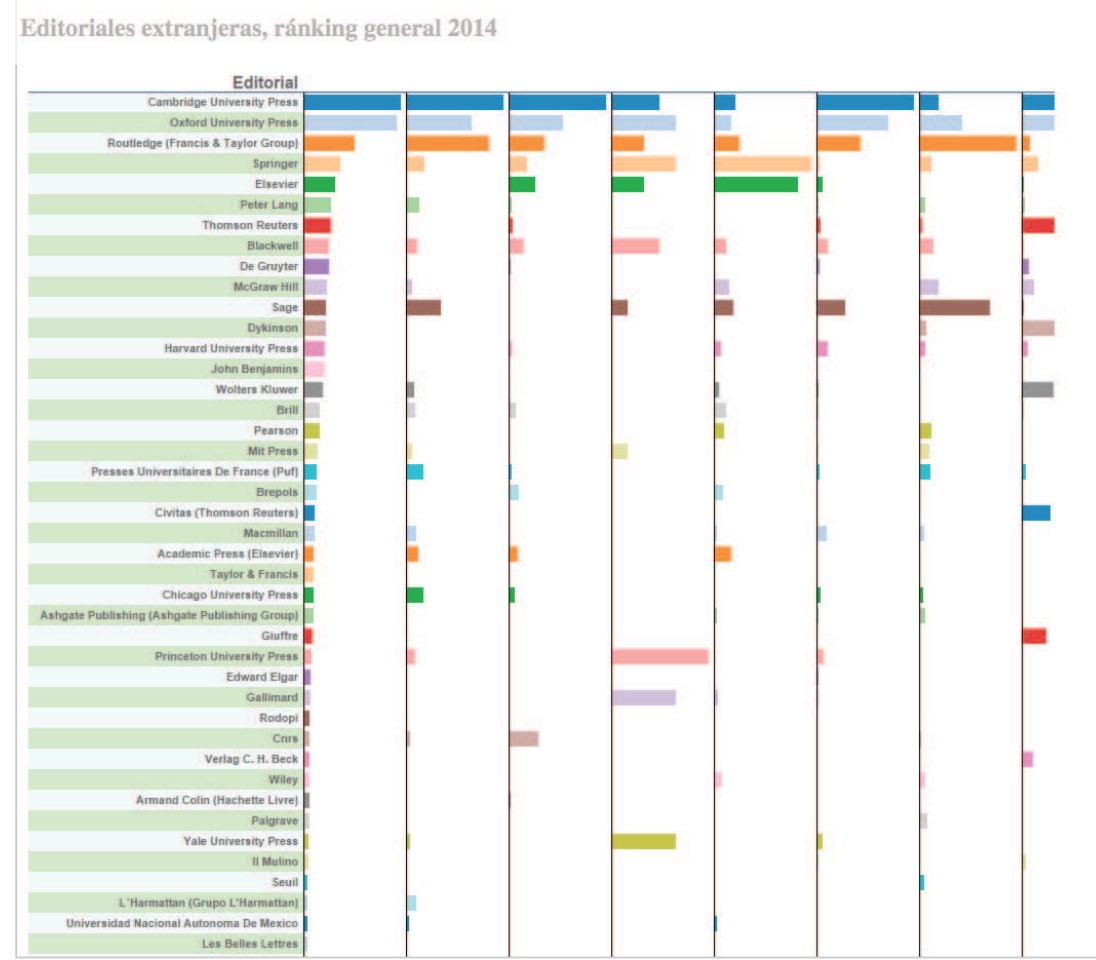

Chart 1. Interactive chart screenshot. Non-Spanish book publishers' prestige. 
in assessment processes and in research and publication(authors, publishers and reviewers). Specialization is also important for any information system.

The Dilve (Distribuidor de Información del Libro Español en Venta) database was used as the source of information for the analysis of the specialization profiles of the various book publishers. Dilve provides numerous fields including a book publisher-title-field. This information allows the aggregation of the titles published by a given publisher according to the frequency of publication in a given discipline. Also, it permits the analysis of the percentage of titles published by each publisher in each discipline and, transposing the data matrix, the number of publishers who publish in a given discipline. In order to calculate these percentages, over 500,000 individual registers have been analyzed.

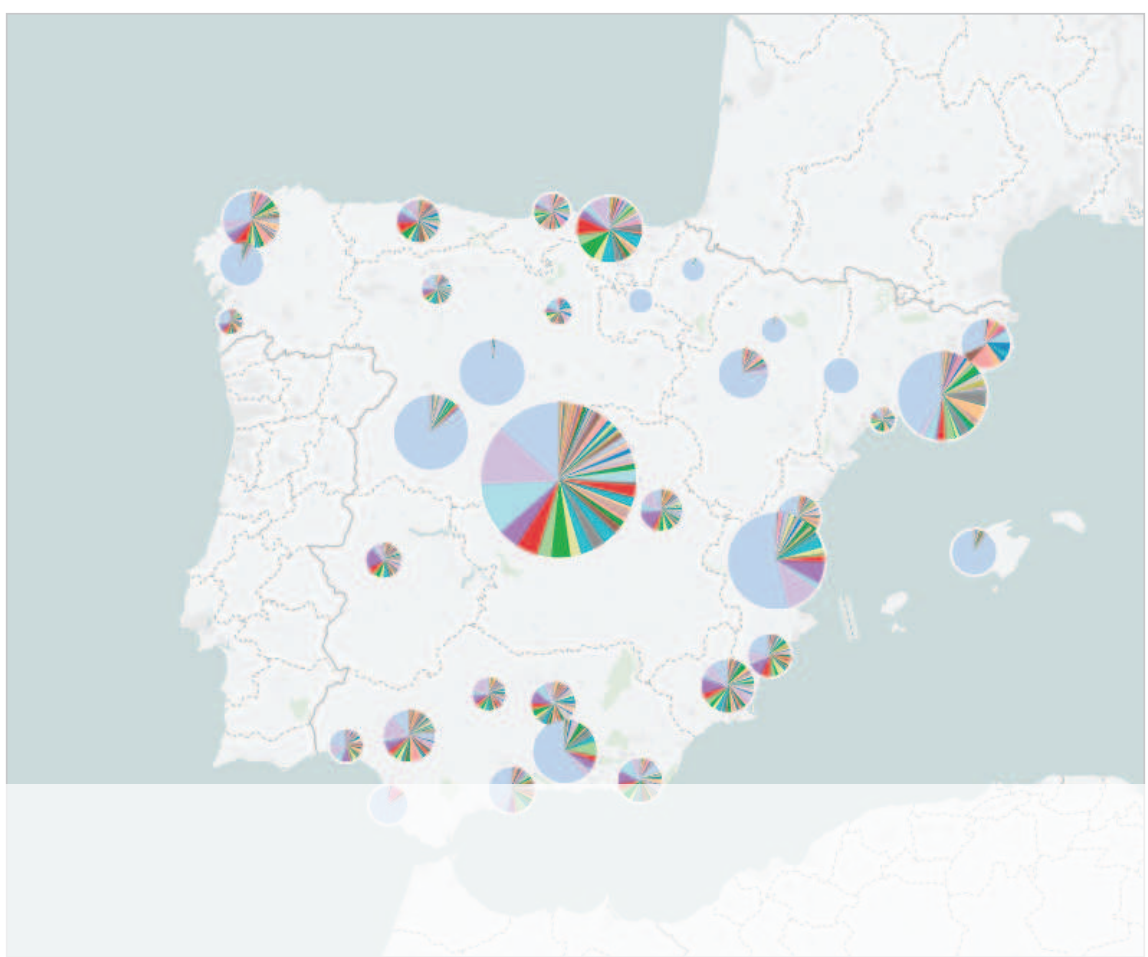

Chart 2. Screenshot of the interactive chart. Titles by discipline for the Spanish University Presses (UNE)

http://ilia.cchs.csic.es/SPI/grafico5.html
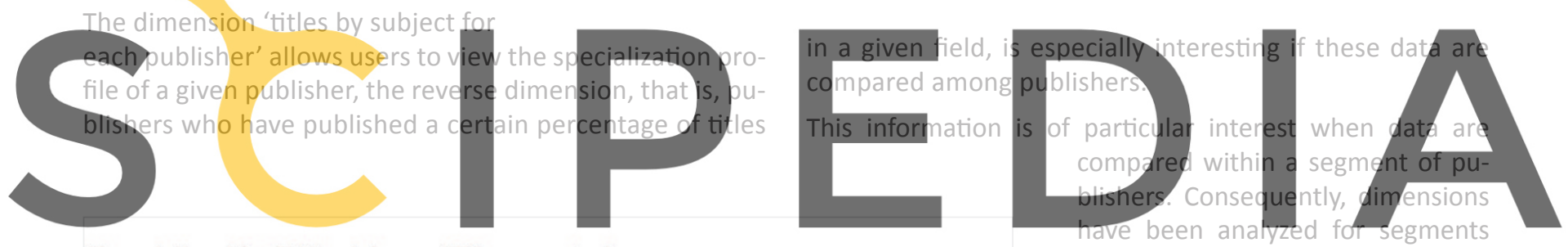

Especialización. Editoriales en SPI por materia

of publishers: those in SPI, UNE pu-

Register for free at https//www.scipedia.com to download the verisfiem mithibutit athessvatermark

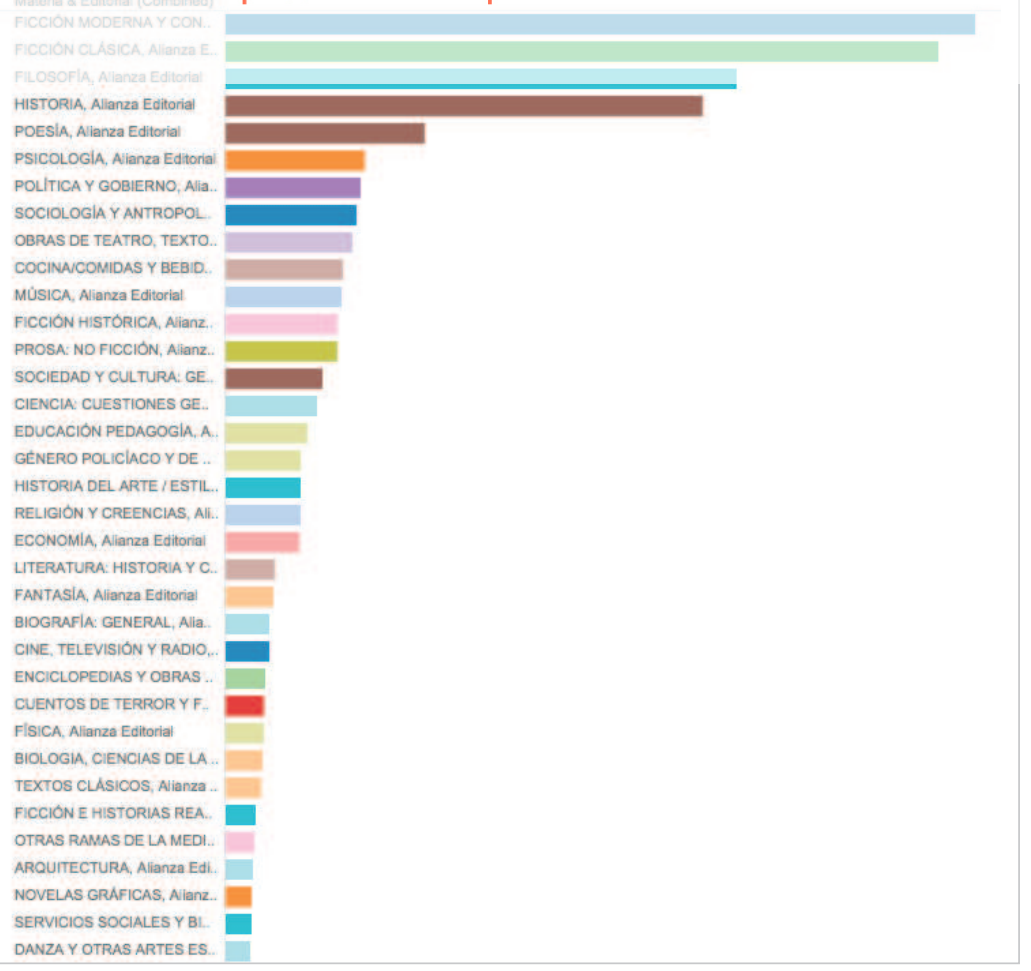

tained in Dilve. In the case of Dilve, an interactive chart has also been developed in order to better reflect the activity of the Spanish University Presses by fields

http://ilia.cchs.csic.es/SPI/une ccaa.html

\subsection{Assessment systems decla- red by publishers}

There is not yet a consensus among the research community regarding the most appropriate model for the assessment of books by book publishers (which is not the case regarding scientific journals). Nevertheless, a better understanding of how procedures are carried out by book publishers provides useful information about the quality of what is published. Book publishers offer almost no publicly available information regarding their procedures (Giménez-Toledo et al., 2014). Given this situation, two surveys were 


\section{Sistemas de revisión de originales}

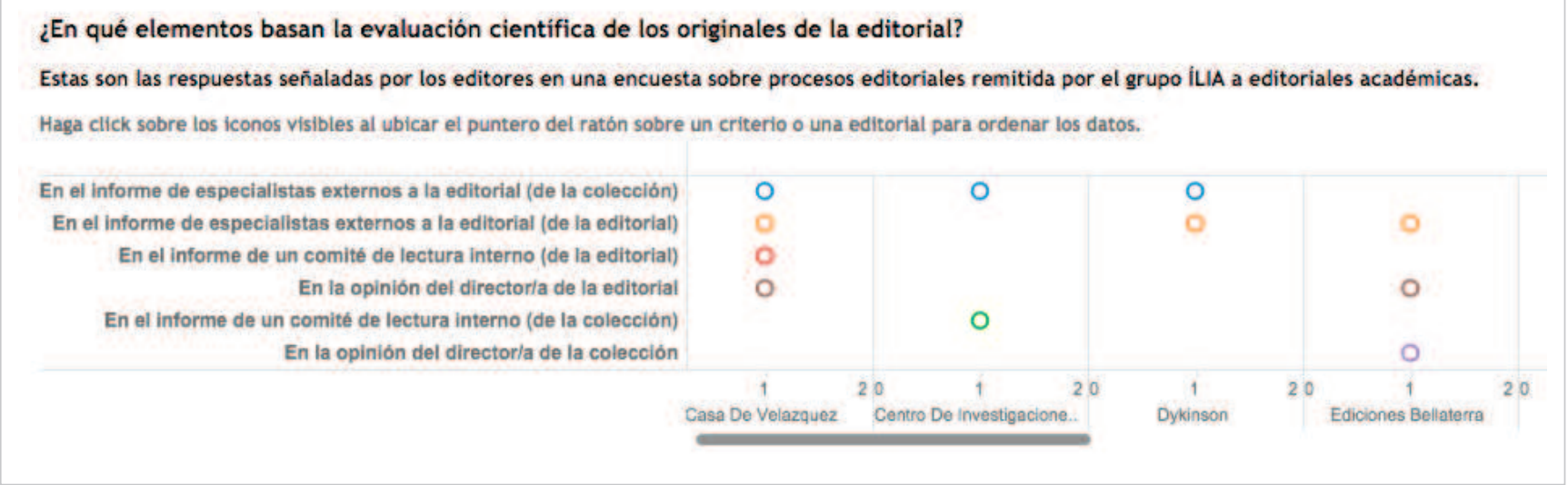

Chart 4. Screenshot of the interactive chart reflecting the assessment systems surveyed publishers use.

sent to Spanish and Latin American book publishers requesting information related to their selection procedures. The respondents were able to provide information about review procedures and publication types. The results to date (113 book publishers) can be found on:

http://ilia.cchs.csic.es/SPI/revision_originales.html

This study is ongoing and book publishers are encouraged to

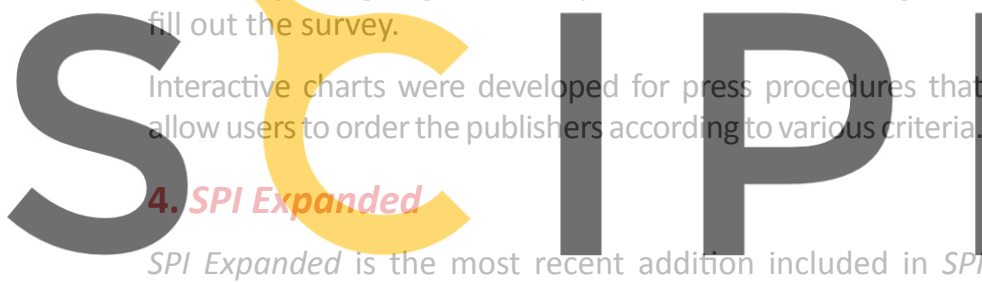

and analyzes the presence of over 2,700 book publishers in

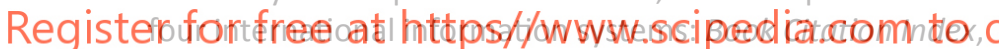
Scopus, the Norwegian Lists, and SPI. The information provided for each publisher facilitates a better understanding of publishers visibility and international recognition; and SPI Expanded also provides information about commercial databases showing a different coverage pattern with respect to public information systems. The latter seem to be more closely aligned with the needs of institutions, are less restrictive, and provide an answer to the diversity of book publishers operating in the humanities and the social sciences while also taking into account book publishers which publish in languages other than English.

This product can be found at:

http://ilia.cchs.csic.es/SPI/expanded_index.html

\section{Search options in SPI}

Besides the information accessible through the various tables and specific interactive graphics, SPI searchable database is available at:

http://ilia.cchs.csic.es/SPI/buscador_spi.php

The search options include book publishers' prestige (ICEE, relative position, and number of publishers in the ranking), specialization (first and second specialization fields, number of titles in each discipline, and percentage they represent of all the titles published in that discipline), manuscript review system used by book publishers, and publisher presence or absence in international information systems.

\section{Final remarks on the use of SPI}

SPI was developed for two reasons: to provide information and indicators for the scientific assessment of publishers and as a tool for authors, libraries, and scholarly publishers.
SPI has a section that describes the proper use of the infor-
mation system; it includes limitations as well as precautions.
The first published results of \$PI were the prestige rankings
and are considered as orieptations for the chiteria develp-
ped by Cneai (Eneai, 2014) for the fields 10 (history, geography and arts) from 2013, and 11 (philosophy, philology and

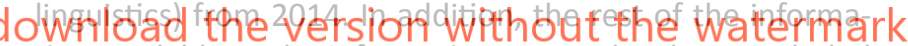
tion available at the information system has been included in order to provide a more complete view of each of the publishers. In the future the system will become more complete and rich with information through the continuous work carried out at ILIA; we expect the continued support and collaboration of book publishers and publishers associations such as UNE (the Union of Spanish University Presses), AEM (Association of Publishers from Madrid), Eulac (Association of Latin American and the Caribean University Presses), and the FGEE (Federation of Publishers' Guilds of Spain). Since the aim of the research group is the study of book publishers with the book publishers, we wish to thank all them for the progress achieved through SPI.

\section{References}

Adams, Jonathan; Testa, James (2011). "Thomson Reuters Book Citation Index". In: Noyons, Ed; Ngulube, Patrick (eds.). The $13^{\text {th }}$ Conf of the Intl Society for Scientometrics and Informetrics. Durban, South Africa: ISSI, Leiden University and University of Zululand, pp. 13-18.

Adler, Robert; Ewing, John; Taylor, Peter (2009). "Citation statistics". Statistical science, v. 24, n. 1, pp. 1-14.

http://arxiv.org/pdf/0910.3529.pdf

http://dx.doi.org/10.1214/09-STS285 
Engels, Tim C.; Ossenblok, Truyken L.; Spruyt, Eric H. (2012). "Changing publication patterns in the social sciences and humanities, 2000-2009". Scientometrics, v. 93, n. 2, pp. 373-390. http://dx.doi.org/10.1007/s11192-012-0680-2

España (2014). “Resolución de 26 de noviembre de 2014, de la Comisión Nacional Evaluadora de la Actividad Investigadora, por la que se publican los criterios específicos aprobados para cada uno de los campos de evaluación". BOE, n. 290, 1 de diciembre, pp. 98204-98219.

http://www.boe.es/diario_boe/txt.php?id=BOE-A-2014-12482

Frølich, Nicoline (2011). "Multi-layered accountability. Performance-based funding of universities". Public administration, v. 89, n. 3, pp. 840-859.

http://dx.doi.org/10.1111/j.1467-9299.2010.01867.x

Giménez-Toledo, Elea; Fernández-Gómez, Sylvia; TejadaArtigas, Carlos-Miguel; Mañana-Rodríguez, Jorge (2014).

"From book publishers to authors: Information transparency in web sites". Journal of scholarly publishing, v. 46, n. 1, pp. 71-88.

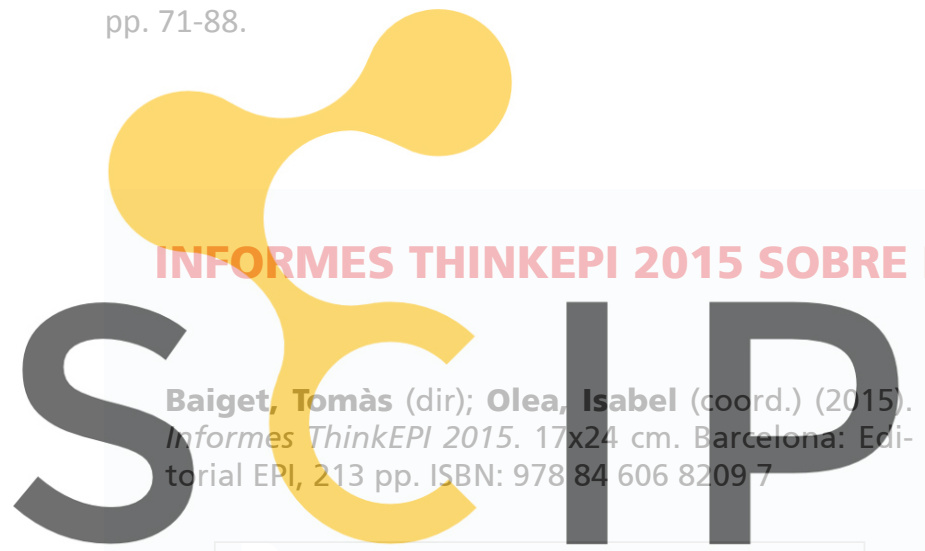

Register for free at https//www.scipedia.com to

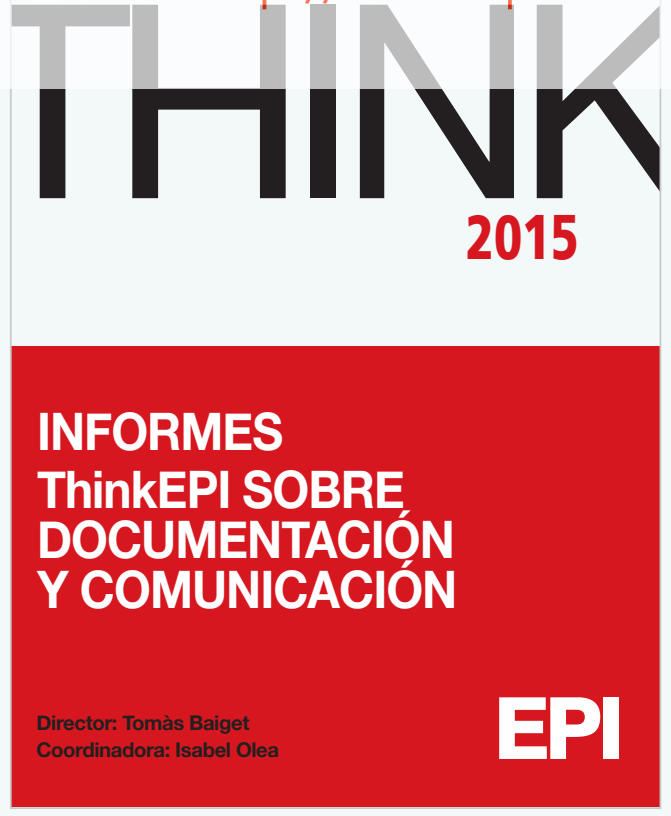

Pedidos: Isabel Olea

Tf.: 608491521

epi.iolea@gmail.com http://dx.doi.org/10.3138/jsp.46.1.004

Giménez-Toledo, Elea; Tejada-Artigas, Carlos-Miguel; Mañana-Rodríguez, Jorge (2013). "Evaluation of scientific books' publishers in social sciences and humanities: Results of a survey". Research evaluation, v. 22, n. 1, pp. 64-77. http://dx.doi.org/10.1093/reseval/rvs036

Hicks, Diana M. (2004). "The four literatures of social science". En: Moed, Henk (ed.) Handbook of quantitative science and technology research. Dordrecht: Kluwer Academic.

http://citeseerx.ist.psu.edu/viewdoc/download?doi=10.1.1. 10.500\& $\mathrm{rep}=$ rep1\&type $=p d f$

http://dx.doi.org/10.1007/1-4020-2755-9_22

Kumar, Malhar N. (2010). "The import of the impact factor: fallacies of citation-dependent scientometry". Bulletin of The Royal College of Surgeons of England, v. 92, n. 1, pp. 26-30. http://publishing.rcseng.ac.uk/doi/pdf/10.1308/147363510X481647

Wilcox, Allen J. (2008). "Rise and fall of the Thomson impact factor". Epidemiology, v. 19, n. 3, pp. 373-374. http://dx.doi.org/10.1097/EDE.0b013e31816a1293

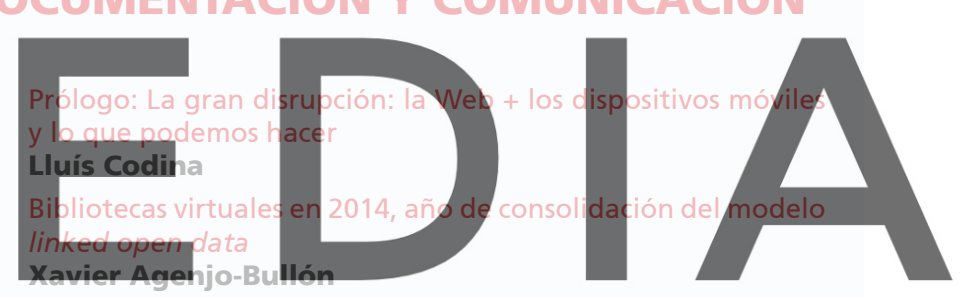

Tecnología móvil y bibliotecas en 2014: ampliando el concepto

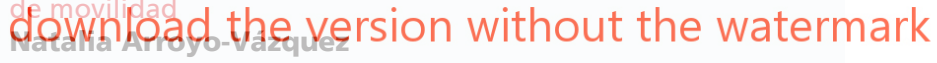

Encuesta internacional de automatización de bibliotecas

Marshall Breeding

Moocs: estado actual, retos y oportunidades

Josep Cobarsí-Morales

Los libros electrónicos: principales tendencias y prospectiva José-Antonio Cordón-García

Servicios de suscripción de libros electrónicos: modelos y tendencias

\section{José-Antonio Cordón-García}

Comunicación científica en 2014. En torno a la 'altmetría' Rodrigo Costas

Informe de la situación de los medios sociales en el sector de la información y la documentación en 2014 y prospectiva 2015 Nieves González-Fernández-Villavicencio

Medios de comunicación digitales en 2014: un balance alternativo

\section{Pere Masip}

Acceso abierto en 2014: se sigue avanzando Remedios Melero y Ernest Abadal

Web semántica. Informe de situación 2014 Juan-Antonio Pastor-Sánchez y Tomás Saorín

Resumen de actividades de IFLA, Eblida, Liber y Fesabid en 2014

Glòria Pérez-Salmerón

Informe de situación 2015: profesión y formación universitaria Carlos-Miguel Tejada-Artigas 